\title{
TREND CURAH HUJAN EKSTREM HARIAN BERDASARKAN DATA PERSIANN-CCS DI KEPULAUAN BANGKA BELITUNG
}

\author{
AKHMAD FADHOLI * \\ Stasiun Meteorologi Depati Amir Pangkalpinang, \\ Jl. Bandara Depati Amir Pangkalpinang, Telp. 0717-436894 \\ *email : akhmad.fadholi@mail.ugm.ac.id
}

\begin{abstract}
Abstrak. Curah hujan ekstrem di Kepulauan Bangka Belitung memiliki dampak banjir sehingga perlu adanya kajian terkait trend kejadian curah hujan ekstrem. Namun, belum cukupnya data observasi lapangan membuat pemanfaatan data curah hujan berbasis satelit perlu dilakukan. Data curah hujan satelit dari Precipitation Estimation from Remotely Sensed Information using Artificial Neural Networks (PERSIANN) - Cloud Classification System (CCS) yang merupakan data curah hujan berbasis satelit dengan resolusi spasial terbaik saat ini yaitu $0.04^{\circ}$. Penelitian ini bertujuan untuk mengetahui distribusi trend kejadian curah hujan ekstrem di Kepulauan Bangka Belitung menggunakan data PERSIAN-CCS dan analisisnya. Metode penentuan threshold ekstrem dengan Persentil 95, 98, dan 99, serta threshold $50 \mathrm{~mm}$ dan $100 \mathrm{~mm}$ seperti yang digunakan oleh BMKG. Beberapa threshold tersebut digunakan untuk menentukan jumlah kejadian curah hujan ekstrem tiap tahunnya. Regresi linear digunakan untuk menentukan slope sebagai trend naik atau turun. Mann-Kendal Test digunakan dalam penentuan signifikansi laju trend dari nilai slope. Hasil pengolahan data pada menunjukkan trend kenaikan signifikan kejadian curah hujan ekstrem Persentil 95 berkisar antara 3 - 11 kali perdekade, Persentil 98 dengan kisaran 2 - 6 kali, dan Persentil 99 dengan kisaran 1 - 4 kali. Kejadian curah hujan $\geq 50$ mm naik signifikan antara 3 - 14 kali perdekade dan curah hujan $\geq 100 \mathrm{~mm}$ naik signifikan antara 1 - 3 kali. Kejadian mendominasi hampir seluruh Pulau Bangka dan sebagian Pulau Belitung. Pemetaan trend kenaikan signifikan untuk kejadian curah hujan $\geq 50 \mathrm{~mm}$ hampir sama dengan Persentil 95, sedangkan $\geq 100 \mathrm{~mm}$ memiliki pola yang hampir sama dengan Persentil 99.
\end{abstract}

Kata kunci: curah hujan ekstrem, PERSIANN-CCS, kepulauan bangka belitung

\begin{abstract}
Extreme rainfall can cause flooding in Bangka Belitung Islands, so it needs a research related to the trend of extreme rainfall events. However, insufficient of field observation data made the use of satellite-based rainfall data was necessary. Estimated rainfall data from Precipitation Estimation from Remotely Sensed Information using Artificial Neural Networks (PERSIANN) - Cloud Classification System (CCS) was one of the best satellite-based rainfall data with $0.04^{\circ}$ spatial resolution. This study aimed to determine spatial distribution and analyze the extreme rainfall events in Bangka Belitung Islands using PERSIAN-CCS data. This study used the $95^{\text {th }}, 98^{\text {th }}$, and $99^{\text {th }}$ percentiles for extreme threshold, and $50 \mathrm{~mm}$ and $100 \mathrm{~mm}$ threshold as used by BMKG. These thresholds used to determine the number of extreme rainfall events each year. Linear regression was used to determine the slope as an indicator for the trend and Mann-Kendal Test used in determining the significance of the trend. The results showed significant increase for trend of $95^{\text {th }}$ percentile extreme rainfall ranged from $3-11$ times/decade, $98^{\text {th }}$ percentile ranged from 2 - 6 times/decade, and $99^{\text {th }}$ percentile ranged from 1-4 times/decade. The $\geq 50 \mathrm{~mm}$ rainfall event increased significantly from $3-14$ times/decade and $\geq 100 \mathrm{~mm}$ events increased significantly from 1-3 times/decade. Spatial distribution of significant trend almost happened in all Bangka Island and parts of Belitung Island. Spatial pattern of significant trend $\geq 50 \mathrm{~mm}$ was almost the same with $95^{\text {th }}$ percentile and, while for $\geq 100 \mathrm{~mm}$ events is similar to $99^{\text {th }}$ percentile.
\end{abstract}

Keywords: extreme rainfall, PERSIANN-CCS, bangka belitung islands

JIIF (Jurnal Ilmu dan Inovasi Fisika), ISSN: 2549-0516 


\section{Pendahuluan}

Curah hujan ekstrem merupakansalahsatupenyebabbencana alam seperti banjir dan tanah longsor [1].Saat ini, kejadian curah hujan ekstrem menjadi isu yang sangat diperhatikan oleh IPCC karena frekuensi dan intensitas yang diperkirakan akan mengalami perubahan serius [2]. Intergovernmental Panel on Climate Change (IPCC) (2014) juga menyebutkan curah hujan ekstrem merupakan salah satu potensi bencana alam di wilayah tropis.Potensi curah hujan ekstrem yang terdapat di wilayah tropisdisebabkan karena adanya gangguan cuaca mulai dari skala global, regional, hingga lokal seperti yang terjadi di wilayah Kepulauan Bangka Belitung. Curah hujan ekstrem di wilayah yang berada di tengah Selat Karimata ini dapat terjadi sebagai dampak fenomena Borneo Vortex, MJO, Cold Surge, maupun aktivitas konvektif lokal [3]. Tercatat tiga kejadian curah hujan ekstrem dengan dampak banjir di Kepulauan Bangka Belitung selama tiga tahun berturut-turut yaitu Februari 2015 dan Februari 2016 di Pulau Bangka dan Juli 2017 di pulau Belitung yang menjadi berita nasional.

Berdasarkan dampak yang ditimbulkan, curah hujan ekstrem dapat didefinisikan sebagai curah hujan dengan nilai yang tinggi mencapai ambang batas satu nilai tertentu atau threshold. WMO (2016) melalui Guidelines on The Defintion and Monitoring of Extreme Weather and Climate Events memberikan dua teknik dalam menentukan nilai ekstrem curah hujan yaitu dengan satu nilai absolut atau dengan perhitungan statistik. Di Indoensia, BMKG sebagai pemegang otoritas informasi meteorologi dan klimatologi menggunakan 2 batas nilai curah hujan ekstrem yaitu $50 \mathrm{~mm}$ untuk hujan lebat dan $100 \mathrm{~mm}$ untuk hujan sangat lebat [4]. Namun demikian, kajian-kajian curah hujan ekstrem dengan menggunakan ambang batas nilai ekstrem dari perhitungan statistic seperti Persentil dan Periode Ulang telah banyak dilakukan di Indonesia.

Penelitian tentang curah hujan ekstrem baik bersifat analisis maupun tinjauan klimatologis di Indonesia masih memiliki kekurangan dalam pemetaan. Analisis kasus atau tinjauan klimatologis sering kali hanya bersifat titik, tanpa bisa menunjukkan distribusi spasial. Kurang rapatnya sebaran titik pengamatan menjadi penyebab utama permasalahan tersebut, sehingga membuka peluang pemanfaatan data estimasi yang berbentuk grid seperti data curah hujan berbasis satelit. Kajian tentang curah hujan ekstrem berbasis data satelit telah banyak dilakukan di Indonesia seperti penelitian Marpaung dkk (2012) menggunakan data Tropical Rainfall Measuring Mission (TRMM) dan Aryastana dkk (2012) menggunakan data Global Satellite Mapping of Precipitattion (GSMaP) [5,6]. Teknologi yang berkembang pesat membuat data curah hujan berbasis satelit terus mengalami perbaikan dan kemajuan sehingga menghasilkan resolusi spasial dan temporal yang semakin baik.

Pada 1997, Center for Hydrometeorology and Remote Sensing (CHRS) Universitas Arizona membangun data curah hujan estimasi yang dikenal Precipitation Estimation from Remotely Sensed Information using Artificial Neural Networks (PERSIANN). PERSIANN menggunakan teknik jaringan saraf tiruan untuk menentukan hubungan antara suhu puncak awan yang diukur sensor gelombang panjang infrared (IR) pada satelit Geostationary Orbiting (GEO) dan tingkat curah hujan dengan koreksi bias dari data Passive Microwave yang diukur oleh satelit Low Earth-Orbiting [7]. Salah satu dari tiga produk PERSIANN adalah PERSIANN-Cloud Classification System (CCS) yang dapat memperkirakan curah 
hujan global dengan resolusi spasial $0,04^{\circ}$ (sekitar $4 \times 4 \mathrm{~km}$ ) dengan algoritma Cloud Clustering dan data IR sebagai data input tunggal [8].

Kualitas data curah hujan lapangan yang balum baik dan masih sedikitnya kajian tentang pemanfaatan data PERSIANN-CCS dalam kejadian curah hujan ekstrem, menjadi alasan utama perlunya kajian curah hujan ekstrem berbasis data PERSIANN-CCS di wilayah yang rawan banjir akibat curah hujan tinggi seperti di Kepulauan Bangka Belitung. Oleh sebab itu, penelitian ini dilakukan dengan tujuan untuk mengetahui distribusi spasial trend kejadian curah hujan ekstrem dan melakukan analisis terhadap trend yang dihasilkan.

\section{Metode Penelitian}

Penelitian ini menggunakan data curah hujan harian produk PERSIANN-CCS dari CHRS - Universitas Arizona selama 15 tahun sejak tanu 2003 hingga 2018. Data PERSIANN-CCS dapat diunduh melalui portal data CHRS (https: //chrsdata.eng.uci.edu) yang dibangun pada tahun 2016 oleh ilmuwan dan programer di CHRS dengan bantuan United Nations Educational Scientific and Cultural Organization-International Hydrological Program (UNESCO-IHP) dan US Army Corps of Engineers International Center for Integrated Water Resources Management (ICIWaRM). Data harian PERSIANN-CCS dapat diunduh dengan format NetCDF (*.nc) dan dapat diekstrak ke dalam format text (*.txt) untuk didapatkan nilai curah hujan perhari tiap koordinat gridnya dengan menggunakan aplikasi NetCDF Operator atau NCO dengan beberapa perinyah seperti $n c k v, n c e a$, dan ncdump. Setelah nilai curah hujan tiap hari beserta titik koordinatnya didapatkan, langkah selanjutnya dapat dilakukan perhitungan dan dipetakan melalui aplikasi ArcGIS.

Kajian ini dilakukan dengan fokus lokasi wilayah daratan Provinsi Kepulauan Bangka Belitung yang berada di antara Pulau Sumatera dan Kalimantan. Penentuan lokasi kajian dengan mempertimbangkan potensi gangguan cuaca di wilayah tersebut yang dapat berdampak pada pertumbuhan awan konvektif yang dapat menghasilkan curah hujan ekstrem. Seperti yang ditunjukkan Gambar 1, Provinsi Kepulauan Bangka Belitung terdisri dari 7 kabupaten (Bangka, Bangka, Barat, Bangka Tengah, Bangka Selatan, Belitung, dan Belitung Timur) dan 1 ibu kota provinsi (Pangkalpinang). Jika, grid data PERSIANN-CCS dengan resolusi spasial 0,04 ditampalkan ke wilayah daratan Kepulauan Bangka Belitung, maka akan dihasilkan sekitar1200 grid yang tiap gridnya akan dikenakan perhitungan.

Metode yang digunakan pada penelitian ini adalah penentuan threshold curah hujan ekstrem dan metode uji signifikansi trend. Metode penentuan threshold curah hujan ekstrem menggunakan metode Persentil seperti yang digunakan oleh Dave dan James (2017) untuk penentuan threshold curah hujan ekstrem menggunakan Persentil 95, 98, dan 99 dengan rumus yang ditunjukkan pada persamaan 1. Selain dengan menggunakan metode Persentil, penelitian ini juga menggunakan nilai absolut sebagai nilai ekstrem berdasarkan ketentuan BMKG yaitu $50 \mathrm{~mm}$ dan 100 $\mathrm{mm}[4]$.

$$
P^{95 ; 98 ; 99}=\frac{i(n+1)}{100}
$$

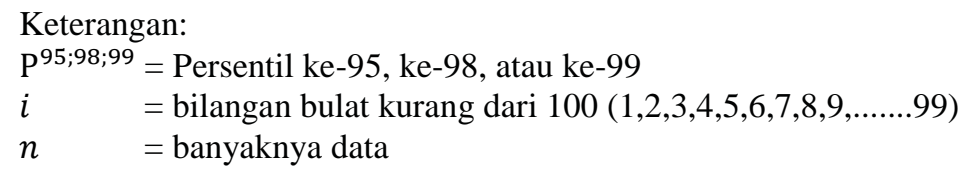




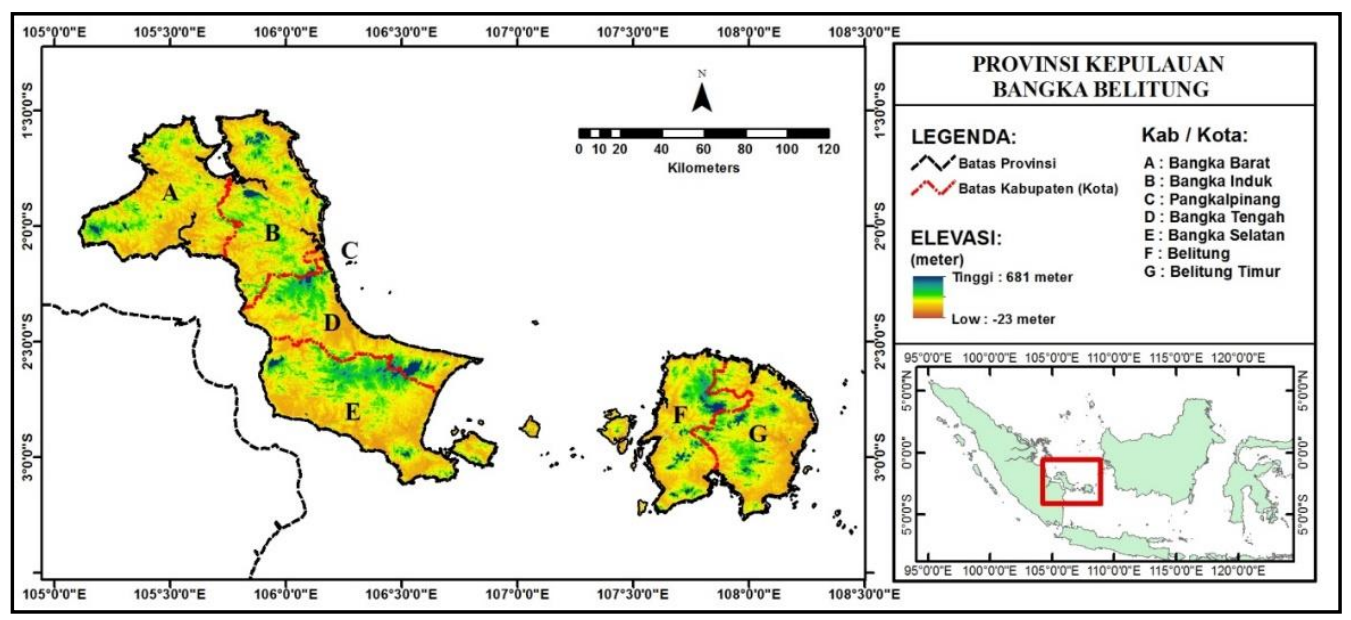

Gambar 1. Lokasi Kajian

Selanjutnya, jumlah kejadian/hari dengan nilai lebih dari atau sama dengan nilai masing-masing persentil maupun nilai ekstrem dari BMKG dalam setiap tahun ditentukan sebagai kejadian/hari dengan curah hujan ekstrem. Penentuan trend dari jumlah kejadian curah hujan ekstrem masing-masing persentil menggunakan fungsi slope dari regresi linear sederhana (Muharsyah, 2012) yang dapat dilihat pada Persamaan 2 [9].

$$
\beta=\frac{n\left(\sum X Y\right)-\left(\sum X\right)\left(\sum Y\right)}{n\left(\sum X^{2}\right)-\left(\sum X\right)^{2}}
$$

Pada Persamaan 2, nilai n adalah jumlah tahun data kejadian curah hujan ekstrem. $X$ adalah urutan tahun data sedangkan $Y$ adalah data jumlah kejadian curah hujan ekstremdari persentil tertentu pada tahun ke $X$. Nilai trend positif menandakan adanya kecenderungan peningkatan kejadian curah hujan ekstrem, sedangkan nilai negatif menunjukkan kondisi sebaliknya. Metode yang dipakai selanjutnya adalah uji signifikansi trend dengan menggunakan Mann-Kendal Test seperti yang pernah dilakukan oleh Supari dkk (2012) dalam kajian curah hujan ekstrem harian di Pulau Jawa [10]. Langkah pertama dalam uji signifikansi Mann-Kendal adalah mencari nilai S untuk mengetahui besaran kesenjangan antar-time series dengan Persamaan 3 dan penjabarannya pada Persamaan 4.

$$
S=\sum_{k=1}^{n-1} \sum_{j=k+1}^{n} \operatorname{sign}\left(x_{j}-x_{k}\right)
$$

\section{Dimana:}

$$
\operatorname{sign}\left(x_{j}-x_{k}\right)=\left\{\begin{array}{c}
1, \text { jika } x_{j}-x_{k}>0 \\
0, \text { jika } x_{j}-x_{k}=0 \\
-1, \text { jika } x_{j}-x_{k}<0
\end{array}\right.
$$

Pada persamaan 3 dan $4, x_{j}$ dan $x_{k}$ adalah dua data jumlah crah hujan ekstrem tertentu pada tahun yang berurutan. $x_{j}$ adalah data jumlah kejadian curah hujan ekstrem dari persentil 95, 98, atau 99 pada tahun $k$, sedangkan $x_{k}$ adalah jumlah kejadian curah hujan ekstrem dari persentil 95, 98, atau 99 pada tahun berikutnya 
atau $k+1$. Langkah selanjutnya yaitu mencari nilai $\mathrm{Z}$ yang menunjukkan tingkat signifikansi kecenderungan atau trend yang terbentuk dengan menggunakan Persamaan 5.

$$
Z=\left\{\begin{array}{cr}
(S-1) / \operatorname{Var}(S)^{0,5} \text { UntukS }>0 \\
0 \quad \text { UntukS }=0 \\
(S+1) / \operatorname{Var}(S)^{0,5} \text { Untuk } S<0
\end{array}\right.
$$

Nilai $\mathrm{Z}$ yang posisitif menunjukkan trend meningkat dan nilai $\mathrm{Z}$ yang megatif menunjukkan trend menurun, sedangkan nilai nol menunjukkan tidak adanya trend. Uji statistik dilakukan pada dua arah (two-tailed) untuk kesignifikanan trend pada level signifikan 95\% $(\alpha=0.05)$. Hipotesis nul tertolak jika nilai absolut $Z$ lebih besar dari $Z_{1-\alpha / 2}$, dimana $Z_{1-\alpha / 2}$ dapat diketahui dari tabel distribusi normal standar kumulatif. Hasil dari uji signifikansi trend dengan metode di atas akan menghasilkan grid-grid di Kepulauan Bangka Belitung yang memiliki trend kejadian curah hujan ekstrem yang signifikan.

\section{Hasil dan Pembahasan}

Hasil pengolahan data berupa nilai threshold curah hujan ekstrem Persentil 95, 98, dan 99 dari masing-masing grid dipetakan sehingga dapat diketahui distribusi atau sebaran spasialnya. Data curah hujan harian selama 15 tahun pada lebih dari 1200 grid yang mencakup wilayah daratan Kepulauan Bangka Belitung menghasilkan nilai threshold ekstrem yang bervariasi. Pada Persentil 95, threshold berkisar antara 44 hingga 58 milimeter seperti yang ditunjukkan pada Gambar 2a. Nilai threshold rendah yang ditampilkan warna hijau tua pada Persentil 95 terlihat mendominasi pesisir bagian timur Pulau Bangka yang mencakup Bangka Induk, Bangka Tengah, Bangka Selatan, Kota Pangkalpinang dan sebagian utara Pulau Belitung. Sedangkan nilai threshold tinggi mendominasi Pulau Bangka bagian barat dan sebagian besar Pulau Belitung. Nilai threshold ekstrem Persentil 98 memiliki kisaran antara 60 hingga 77 milimeter seperti yang ditunjukkan pada Gambar 2b. Distribusi nilai threhold ekstrem Persentil 98 manujukkan nilai threshold tinggi berada di bagian barat Pulau Bangka khususnya Bangka Barat dan Bangka Selatan, serta Belitung bagian barat yaitu Kabupaten Belitung. Pada Persentil 99, nlai threshold tertinggi sebesar 93,7 milimeter dan terendah sebesar 74 milimeter seperti yang ditunjukkan pada Gambar 2c. Distribusi spasial threshold Persentil 99 berbeda dengan dua pola sebaran sebelumnya yang hanya terdiri dari dua skala warna. Distribusi spasial threshold Persentil 99 memiliki tiga skala warna dengan distribusi nilai tertinggi berada di wilyah-wilayah yang kecil seperti sebagian pesisir Kabupaten Bangka Barat dan sebagian kecil Kabupaten Belitung yang ditandai dengan warna merah tua.

Distribusi spasial threshold curah hujan ekstrem dari Persentil 95, 98, dan 99 yang menunjukkan konsentrasi nilai tertinggi berada di Pulau Bangka bagian barat khususnya Kabupaten Bangka Barat dan Bangka Selatan, serta Pulau Belitung bagian barat (kabupaten Belitung). Berdasarkan hasil kajian Fadholi dan Adzani (2017) yang menunjukkan korelasi antara threshold ekstrem terhadap curah hujan tahunan, maka wilayah dengan nilai threshold tertimggi tersebut merupakan wilayah terbasah di Kepulauan Bnagka Belitung [11]. Berdasarkan kajian yang dilakukan sebelumnya, maka hasil pemetaan pada Gambar 2 memiliki kesamaan dengan hasil penelitian Supari dan Setiawan (2013) tentang variabilitas curah hujan data TRMM di wilayah yang sama yang menunjukkan Pesisir Barat Pulau Bangka 
bagian utara dan selatan meruapakan wilayah terbasah di Pulau Bangka, meskipun berbeda untuk Pulau Belitung [12]. Namun demikian, hasil identifikasi dalam kajian ini memiliki perbedaan dengan hasil pemetaan curah hujan yang pertama kali dilakukan untuk wilayah Pulau Bangka oleh Lembaga Meteorologi dan Geofisika (1973) dengan menggunakan data curah hujan sejak tahun 1911 - 1940 yang menunjukkan bahwa Peisisr Timur Pulau Bangka bagian utara atau Kabupaten Bangka sebagai wilayah terbasah.

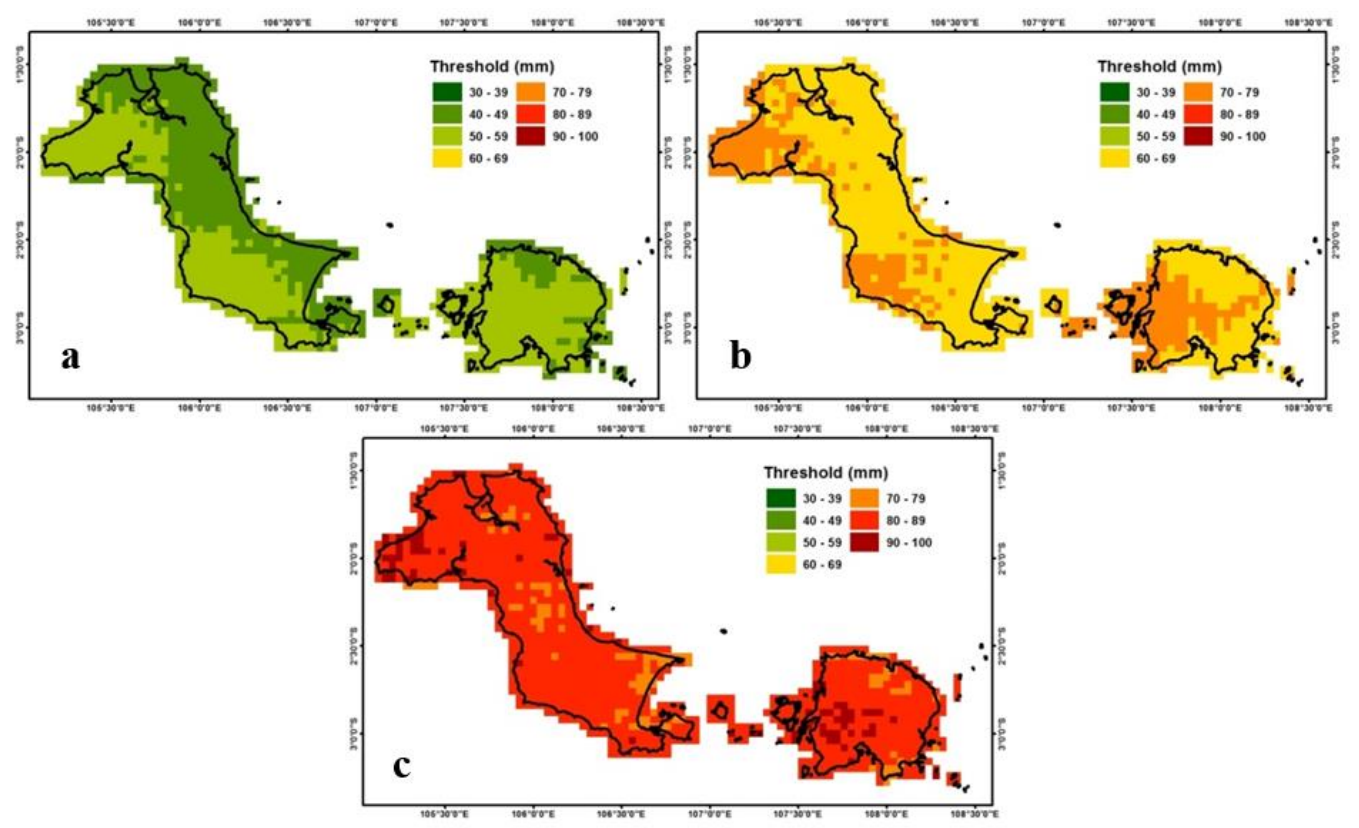

Gambar 2. Distribusi nilai threshold curah hujan ekstrem dengan Persentil 95 (a), Persentil 98 (b), dan Persentil 99 (c) (Sumber: Pengolahan Data)

Perhitungan trend dengan menggunakan persamaan slope dari regresi linear sederhana menghasilkan kisaran yang berbeda untuk kejadian curah hujan ekstrem dari masing-masing threshold ekstrem baik dengan menggunakan metode Persentil maupun dengan nilai absolut. Pada threshold curah hujan ekstrem dengan Persentil 95 diperoleh kisaran nilai slope antara $-0,135$ hingga 1,135 seperti yang daitunjukkan pada Gambar 3a. Nilai slope tertinggi yang dihasilkan dari kejadian curah hujan ekstrem Persentil 95 terkonsentrasi di Pesisir barat Pulau Bangka bagian tengah, pesisir timur bagian selatan, dan Pesisir Barat Pulau Belitung bagian selatan. Gambar 3b menunjukkan distrubusi spasial threshold ekstrem dari Persentil 98 dengan kisaran nilai slope yang terjadi mulai dari -0,076 hingga 0,639. Sebaran nilai slope tertinggi dari kejadian curah hujan ekstrem dengan Persentil 98 menunjukkan konsentrasi nilai tertinggi hanya terdapat di Pesisir Timur Pulau Bangka bagian selatan. Pada threshold curah hujan ekstrem dengan Persentil 99 yang ditunjukkan Gambar 3c, diperoleh nilai slope antara -0,044 hingga 0,432. Pola distribusi spasial trend pada threshold Persentil 99 ini menunjukkan konsentrasi nilai slope tinggi berada di Pulau Bangka bagian selatan. Gambar 3d menunjukkan distribusi spasial nilai slope dari kejadian curah hujan ekstrem $\geq 50 \mathrm{~mm}$ dengan kisaran -0,134 hingga 1,384. Konsentrasi nilai slope tertinggi memiliki pola yang mirip distribusi spasial slope dari kejadian Persentil 95. Sebaran nilai slope untuk kejadian curah hujan $\geq 100$ ditampilkan pada Gambar 3e dengan kisaran antara 0,027 hingga 0,299 yang berpola mirip dengan sebaran nilai slope pada Gambar 3c. 


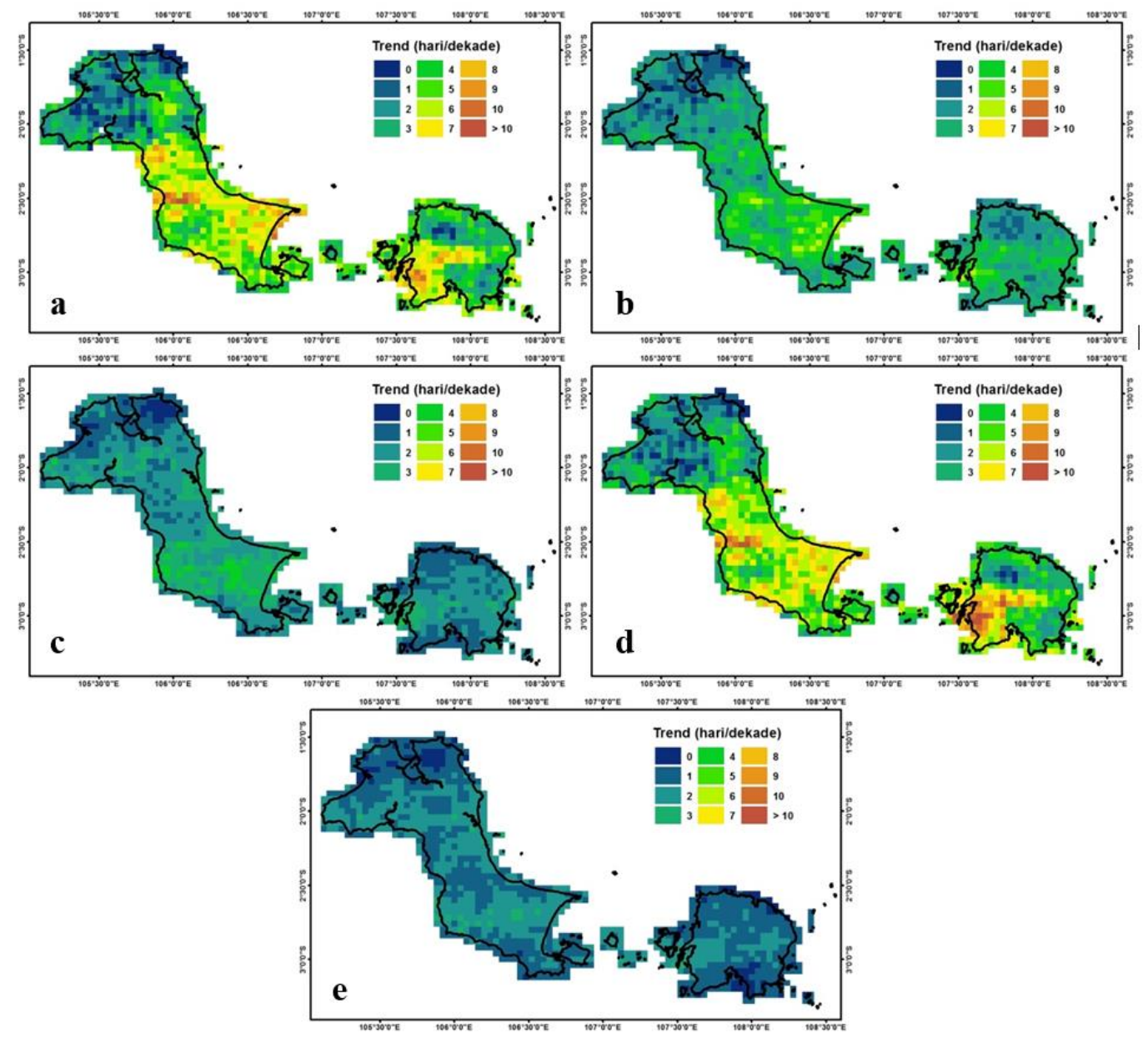

Gambar 3. Distribusi nilai slope kejadian curah hujan ekstrem dari Persentil 95 (a), Persentil 98 (b), Persentil 99 (c), R50 (d), dan R100 (e) (Sumber: Pengolahan Data)

Distribusi nilai slope pada kejadian curah hujan dari Persentil 95 memiliki pola yang mirip dengan kejadian curah hujan $\geq 50 \mathrm{~mm}$, hal ini menunjukkan bahwa threshold Persentil 95 di wilayah Kepulauan Bangka Belitung secara umum memiliki nilai yang tidak jauh dari $50 \mathrm{~mm}$. Hal tersebut juga berlaku untuk kemiripan pola spasial nilai slope dari kejadian curah hujan ekstrem Persentil 99 dengan curah hujan $\geq 100 \mathrm{~mm}$. Secara keseluruhan, distribusi spasial nilai slope dari ketiga threshold Persentil dan dua nilai ekstrem absolut menunjukkan Pulau Bangka dan Belitung bagian utara memiliki nilai slope yang terendah. Jumlah grid PERSIAN-CCS di Kepulauan Bangka Belitung dengan nilai slope $<0,5$ terbanyak terdapat pada threshold $\geq 100 \mathrm{~mm}$ dengan jumlah 79 grid, sedangkan yang terendah pada Persentil 98 dengan jumlah 19 grid. Grid-grid dengan kriteria tersebut juga berlokasi di sekitar wilayah dengan nilai slope rendah.

Distribusi nilai slope sebagai indikator trend yang ditampilkan pada Gambar 3 belum secara pasti menggambarkan potensi perubahan kejadian curah hujan ekstrem, sehingga perlu diketahui grid mana saja yang memiliki trend signifikan. Hasil uji signifikansi melalui Mann-Kendal Test untuk mengetahui konsistensi perubahan jumlah kejadian curah hujan ekstrem tiap tahunnya ditambilkan padaa Gambar 4. 

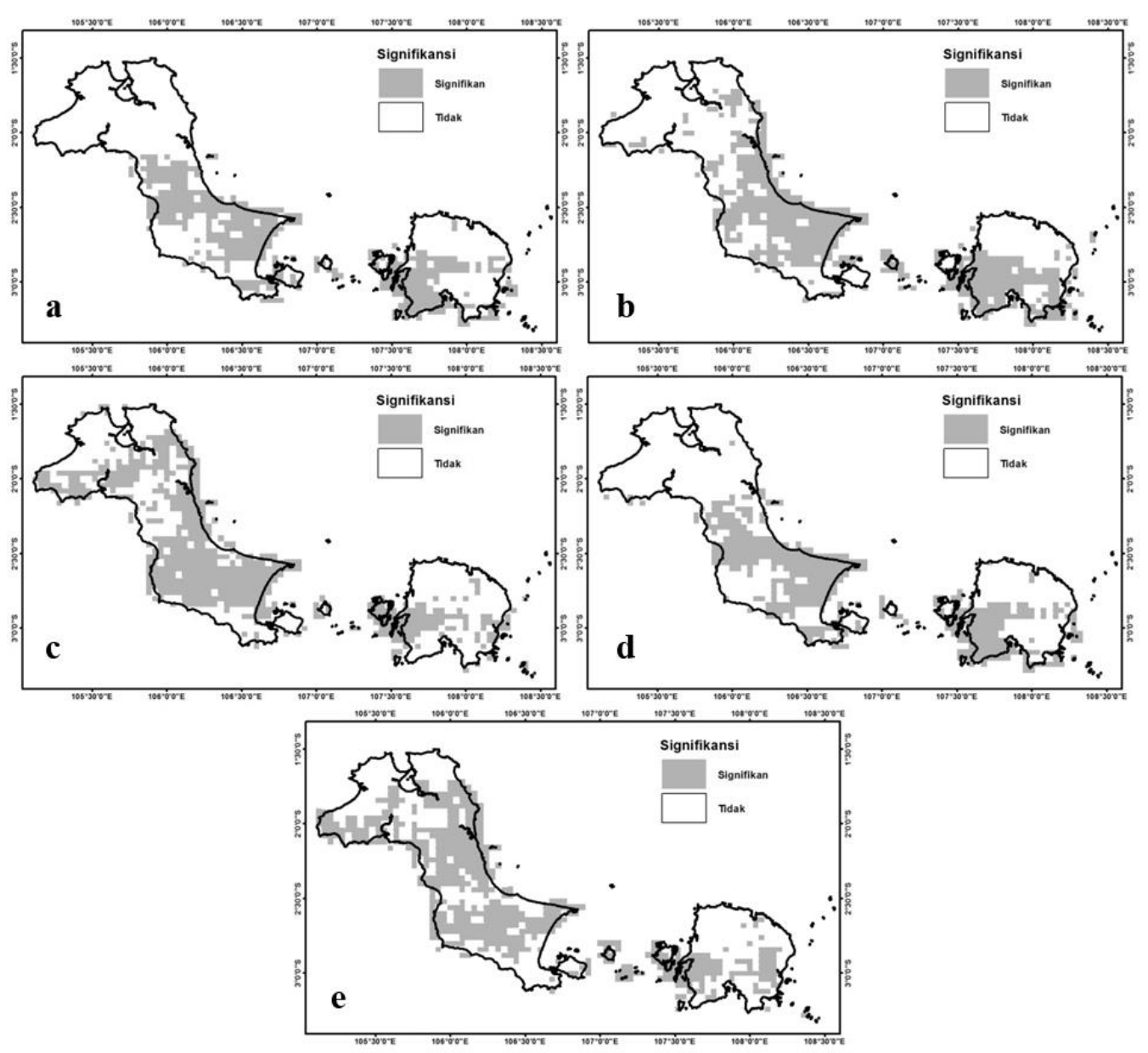

Gambar 4. Signifikansi trend kejadian curah hujan ekstrem dari Persentil 95 (a), Persentil 98 (b), Persentil 99 (c), R50 (d), dan R100 (e) (Sumber: Pengolahan Data)

Uji signifikansi trend dengan menggunakan Mann-Kendal Test menghasilkan gridgrid dengan trend kenaikan kejadian curah hujan ekstrem yang signifikan. Kejadian curah hujan ekstrem yang diperoleh dari threshold curah hujan ekstrem dengan metode Persentil 95 menghasilkan 402 grid dengan trend kenaikan jumlah kejadian curah hujan ekstrem yang signifikan. Pada trhshold ekstrem dengan Persentil 98 diperoleh 510 grid dengan trend kenaikan jumlah curah hujan ekstrem yang signifikan. Sedangkan pada threshold ekstrem dengan metode Persentil 99 diperoleh 548 grid dengan trend kejadian curah hujan ekstrem yang signifikan. Uji signifikansi trend kejadian curah hujan ekstrem dari threshold $\geq 50 \mathrm{~mm}$ menghasilkan 417 grid dengan trend signifikan, sedangkan threshold $\geq 100 \mathrm{~mm}$ menghasilkan 549 grid.

Pemetaan grid dengan trend kejadian curah hujan ekstrem signifikan ditampilkan pada Gambar 4. Trend signifikan kejadian curah hujan ekstrem pada threshold Persentil 95 ditunjukkan Gambar 4a, Persentil 98 ditunjukkan Gambar 4b, dan Persentil 99 di Gambar 4c. Pada nilai ekstreme absolut, grid dengan trend kejadian signifikan untuk curah hujan $\geq 50 \mathrm{~mm}$ ditampilkan Gambar $4 \mathrm{~d}$, sedangkan curah hujan $\geq 100 \mathrm{~mm}$ ditampilkan Gambar 4e. Trend signifikan pada kejadian curah hujan ekstrem threshold Persentil 95 berkisar antara 0,31 - 1,14 kejadian/tahun atau 3 - 11 hari/dekade. Pada kejadian curah hujan ekstrem threshold Persentil 98, trend 
kenaikan signifikan kejadian curah hujan ekstrem berkisar antara 0,17 - 0,64 kejadian/tahun atau 2 - 6 hari/dekade. Kejadian curah hujan ekstrem pada threshold Persentil 99 meningkat dengan signifikan pada kisaran 0,09 - 0,43 kejadian/tahun atau 1 - 4 hari/dekade. Trend signifikan pada kejadian curah hujan ekstrem threshold $\geq 50 \mathrm{~mm}$ berkisar antara 0.33 - 1,38 kejadian/tahun atau 3 - 14 hari/dekade, sedangkan trend signifikan pada kejadian curah hujan ekstrem threshold $\geq 100 \mathrm{~mm}$ berkisar antara 0.08 - 0,3 kejadian/tahun atau 1 - 3 hari/dekade. Trend kejadian curah hujan ekstrem semakin rendah seiring tingginya threshold persentil yang ditentukan. Hasil ini menunjukkan bahwa semakin tinggi curah hujan memiliki peluang kejadian yang makin kecil.

Hasil yang ditampilkan pada Gambar 4 menunjukkan bahwa adanya perubahan frekuensi kejadian curah hujan yang signifian di Kepulauan Bangka Belitung berdasarkan data PERSIAN-CCS. Perubahan yang dimaksud adalah peningkatan kejadian curah hujan ekstrem yang signifikan meskipun tidak di semua wilayah. Hasil kajian dengan data satelit ini dapat berbeda dengan hasil yang dilakukan dengan menggunakan data lapangan. Namun, hasil ini dapat menjadi suatu potensi perubahan frekuensi kejadian curah hujan ekstrem yang signifikan seperti yang telah ditemukan di beberapa wilayah di Indonesia seperti di Jawa dan Sumatera. Di Pulau Jawa, pesisir utara khususnya di wilayah Jakarta menunjukkan trend peningkatan jumlah kejadian curah hujan ekstrem pada Persentil 95 [13], sedangkan hasil uji trend kejadian curah hujan ekstrem dengan threshold $\geq 50 \mathrm{~mm}$ mengalami trend penurunan di Pesisir Utara Jawa Tengah [14]. Di Sumatera Barat, Nugroho dan Febriamansyah (2012) dalam kajiannya tentang proyeksi perubahan iklim di wilayah Provinsi Sumatera Barat menemukan adanya trend penurunan kejadian curah hujan ekstrem dari Persentil 95 dan 99 [15].

Peningkatan frekuensi kejadian curah hujan ekstrem dapat menjadi salah satu dampak pemanasan global [16]. Hasil penelitian Siswanto dkk (2015) menunjukkan peningkatan kejadian curah hujan ekstrem yang signifikan berasosiasi dengan peningkatan aktivitas thunderstorm yang terjadi pada malam hari [13]. Siswanto dkk (2015) memaparkan bahwa kejadian thunderstorm di malam hari di Jakarta berkaitan perubahan (peningkatan) suhu udara permukaanakibat urban heat island yang juga pernah disimulasikan oleh Lin dkk (2011) di Taiwan bagian utara $[13,17]$. Peningkatan suhu udara permukaan terutama di malam hari sebagai masukan panas antropogenik merupakan salah satu dampak dari perubahan signifikan penggunaan lahan yang disebutkan oleh Sepherd dan Jin, 2004 [18]. Peingkatan suhu udara bersama perubahan albedo, kekasaran permukaan, dan evapotranspirasi dapat memberikan pengaruh signifikan pada sirkulasi atmosfer yang menghasilkan penguatan aktivitas konvektif dan dan berdampak curah hujan yang tinggi [19,20].

\section{Kesimpulan}

Hasil pengolahan data curah hujan harian PERSIANN-CCS selama 15 tahun menunjukkan threshold ekstrem dengan metode Persentil dan nilai absolut dengan nilai tinggi berada di bagian barat baik Pulau Bangka dan Pulau Belitung. Hasil uji signifikansi trend menunjukkan bahwa semakin tinggi nilai threshold, semakin banyak juga grid signifikan yang dihasilkan. Pemetaan hasil uji signifikansi trend kejadian curagh hujan ekstrem dari semua threshold menunjukkan bahwa semakin tinggi threshold akan menghasilkan jumlah grid dengan trend signifikan yang semakin banyak dan merata. Selain itu, semakin tinggi nilai threshold akan menghasilkan trend peningkatan jumlah kejadian curah hujan ekstrem yang 
semakin kecil pula. Pada Persentil 95, trend kejadian naik signifikan berkisar antara 3 - 11 kali perdekade. Persentil 98 menghasilkan trend naik signifikan pada kisaran 2 - 6 kali perdekade, dan Persentil 99 menghasilkan trend naik signifikan dengan kisaran $1-4$ kali perdekade. Trend peningkatan signifikan pada threshold $\geq 50$ mm berkisar antara 3 - 14 kali perdekade, sedangkan pada $\geq 100 \mathrm{~mm}$ berkisar antara $1-3$ kali perdekade. Upaya lebih lanjut untuk mengetahui penyebab terjadinya trend kenaikan kejadian curah hujan ekstrem perlu dilakukan agar resiko bahaya bencana hidrometeorologi dapat ditekan.

\section{Ucapan Terima Kasih}

Terimakasih yang sebesar-besarnya atas dukungan rekan-rekan kantor terutama Rizki Adzani yang selalu memberi dukungan penuh dalam pemecahan pengolahan data PERSIANN-CCS, serta keluarga yang selalu mendoakan untuk kelancaran dan kesuksesan penulis.

\section{Daftar Pustaka}

1. L.M.V. Carvalho, C. Jones, B. Liebmann, Extreme Precipitation Events in Southeastern South America and Large-Scale Convective Patterns in the South Atlantic Convergence Zone, Journal of Climate, Vol. 15 (2002), p. 2377-2394.

2. K.E. Trenberth, P.D. Jones, P. Ambenje, R. Bojariu, D. Easterling, Klein Tank, A.M.G., et.al., Observations: Surface and Atmospheric Climate Change, In: Climate Change 2007. The Physical Science Basis. Cambridge University Press.Cambridge. United Kingdom and New York, New York, USA, (2007).

3. K.F.N. Isnoor, P.U. Firdianto, A. Susilawati. Studi tentang Fenomena Borneo Vortex terhadap Variabilitas Awan di Kalimantan Barat (Studi Kasus Tanggal 11-13 Januari 2018). JIIF (Jurnal Ilmu dan Inovasi Fisika). Vol. 02. No. 02 (2018), p. $127-136$.

4. A. Fadholi, R. Adzani. Perbandingan Curah Hujan Ekstrem Berbasis Data Satelit antara GSMaP dan CHIRPS di Pulau Belitung. Prosiding Seminar Nasional 4 Pengelolaan Pesisir dan Daerah Aliran Sungai, (2018), p. 173-180

5. S. Marpaung, D. Satiadi, T. Harjana. Analisis Kejadian Curah Hujan Ekstrem di Pulau Sumatera Berbasis Data Satelit TRMM dan Observasi Permukaan. Jurnal Sains Dirgantara. Vol. 9. No.2 (2012).

6. P. Aryastana, T. Tanaka, M.S. Mahendra. Characteristic of Rinfall Pattern Before Flood Occur in Indonesia Based on Rainfall Data From GSMaP. Ecotrophic, Vol. 7, Issues 2 (2009), p. 100-110.

7. S. Sorooshian, K. Hsu, X. Gao, H. Gupta, B. Imam, D. Braithwaite. Evaluation of PERSIANN System Satellite-based Estimates of Tropical Rainfall. Bull. Amer. Meteor. Soc. Vol. 81 (2000), p. 2035-2046.

8. Y. Hong, K. Hsu, S. Sorooshian, X. Gao. Precipitation Estimation From Remotely Sensed Imagery Using An Artificial Neural Network Cloud Classification System. J. A Hall. Meteor. Vol. 43 (2004), p. 1834-1853.

9. R. Muharsyah. Deteksi Kecenderungan Perubahan Temperatur Menggunakan Regresi Linear dan Uji Mann-Kendall di Sejumlah Wilayah Papua. Buletin Megasains, Vol. 3, Issues 2 (2012), p. 77-85. 
10. S. Supari, S. Sudibyakto, J. Ettema, E. Aldrian. Spatiotemporal Characteristics of Extreme Rainfall Events Over Java Island, Indonesia. IJG, Vol. 44, Issues 1 (2012), p. $62-86$.

11. A. Fadholi, R. Adzani, R. Normal Curah Hujan Kepulauan Bangka Belitung Berbasis Data Climate Hazards Group Infra-Red Precipitation with Stations (CHIRPS). Prosiding Seminar Nasional Geografi, (2017), p. 259-267.

12. S. Supari, N. Setiawan. Variabilitas Curah Hujan di Kepulauan Bangka Belitung Berdasarkan Data TRMM Tervalidasi. Jurnal Meteorologi dan Geofisika. Vol. 14, No. 1 (2013), p. 11- 20.

13. S. Siswanto, G.J. van Oldenborgh, G. van der Schrier, R. Jilderdab, B. van den Hurkb. Temperature Extreme Precipitation, and Diurnal Rainfall Changes in the Urbanized Jakarta City During the Past 130 Years. Int. J. Climatol, Vol. 36, Issues 9 (2015), p. 3207-3225.

14. S. Siswanto, S. Supari. Rainfall Changes Over Java Island, Indonesia. Journal of Environment and Earth Science, Vol. 5, Issues 14 (2015).

15. S. Nugroho, R. Febriamansyah. Deteksi dan Proyeksi Perubahan Iklim Di Wilayah Sumatera Barat. Topik Khusus Penelitian Program Pascasarjana Preliminary Findings, (2012).

16. G.P. Singh, J.H. Oh. Recent Trend in Temperature and Precipitation Extremes over India. World Meteorological Organization, (2016).

17. C.Y. Lin, W.C. Chen, P.L. Chang, Y.F. Sheng. Impact of The Urban Heat Island Effect on Precipitation Over A Complex Geographic Environment in Northern Taiwan. J. Appl. Meteorol. Climatol, Vol. 50 (2011), p. 339-353.

18. M.J. Shepherd, M. Jin. Linkages Between The Built Urban Environment and Earth's Climate System. EOS Trans, Vol. 85, Issues 23 (2004), p. 227-228.

19. R.A. Pielke, J. Adegoke, A. BeltráN-Przekurat, C.A. Hiemstra, J. Lin, U.S. Nair, D. Niyogi T.E. Nobis. An Overview of Regional Land-Use and LandCover Impacts on Rainfall. Tellus B, Vol. 59 (2011), p. 587-601.

20. M. Lei, D. Niyogi, C. Kishtawal, R.A. Pielke, A. Beltrán-Przekurat, T.E. Nobis, S.S. Vaidya. Effect of Explicit Urban Land Surface Representation on The Simulation of The 26 July 2005 Heavy Rain Event over Mumbai, India, Atmos. Chem. Phys., Vol. 8 (2008), p. 5975-5995 